\title{
The glonacal climate in education: Reconstituting the culture of evidence and tradition of intervention in humanities
}

\author{
Nena Padilla-Valdez \\ Professor, Universiti Teknologi, Brunie \\ *Corresponding Author: Nena Padilla-Valdez \\ Email: nenapadillavaldez@gmail.com
}

\begin{abstract}
More than ever, Humanities and all allied disciplines are stepping up into the pathway of trends, innovations and initiatives. Among the many and varied social providers, the academic world stands as the most visible, accessible and tangible driver-agent of systemic reforms within which fundamental structure of the change orbits. Evolutionary hangovers such as those structures or behaviors that used to be adaptive and bear positive effects on reproductive performance has declined or waned due to the drastic change conditions arising from the various layers of the socio-ecological system. In view of responsiveness, a forced-shift from the conventional paradigm to the expansive and inclusive change sphere may render repurcussions which in due course settle both as a hangover of cultural evolution and as a catalyzer of a revolution of change and learning. This paper argues that tightening up the soft-skilled sciences are critical and powerful blocks in building innovative talents, who by virtue of the unprecedented challenges, are globally accepted, recognized and refereed. Also, it describes the evidences specifically the benefits and vast opportunities pummelled by the waves of technological changes and globalizational climate shifts. From this perspective, Humanities education must brace itself on a recursive investigations from competing social and pedagogical tensions to the glonacal (global, national, local) value of knowledge and meaning.
\end{abstract}

Keywords: Glonacal climate, Multiversities, Culture of evidence, Tradition of intervention.

\section{Introduction}

Most, if not all, educational systems are underway evolving as global communities; they too, must cultivate a fortified view of practices drawn from global perspective. Looking beyond geographic boundaries from the local to the the global sphere denotes a cross-cultural mindset that embraces differences between societies and countries and leadership practices that span worldwide, international and intercultural (Chin \& Trimble). ${ }^{1}$ It is a glonacal view associated with the examination of differences and evidences based on economic, political and cultural entities.

Zooming into the existing educational climate, systemic changes manifest themselves into tangible outcomes typified as organizational shifts and initiatives. The shape of the system is thus contoured by a series of shifts and interventions, internally and externally. For instance, modification of programs, internationalization of delivery structures and mechanisms, and upskilling of human resources, among others bear multi-trajectories that transcend and cross over the ecological spheres: microsystem, mesosystem, exosystem, macrosystem and chronosystem. The continuous pattern of shifts and turns engenders a fertile ground for a new breed of university to thrive, the 'multiversity'(Marginson) ${ }^{2}$. Perceived as a spring or well of knowledge, multiversities run through an array of tangible and interconnected networks as indicated by the challenges of transition into the status of Industrial Revolution 4.0, a genre which requires both the ciritical utilization of technology and the cultivation of a critical mass of thinkers. They comprise the pool of self-engaged professionals who have the absorptive capability to propel uncertainties and tensions into endless opportunities to learn and change. In reality, local talents specifically in the Arts and Humanities are believed skeptical and slow to adapt and adopt. Support explanations of this change pace are varied. For instance, Owens and Valesky ${ }^{3}$ sustained the belief that the distinctive mission of education is definitive of its organizational direction and/or change. Simply, the uniqueness of the school is codified in its philosopy, vision, and mission; hence, in addressing transitions, local talents (i.e. practitioners and stakeholders) are inherently apt to become responsive due to power structures and relationships. From an inclusive and holistic perspective, it is stressed that schools are open systems where the degree of interactions varies to allow the input-output transfer for the attainment of system goals and objectives. On both counts, this open system alludes a rigid and fast-changing climate and a new breed of practitioners who can translate the oral, ethical and aesthetic principles into the language of change and shared social meanings of the world. Reconstituting the essence of thoughts and experiences in a very pluralistic climate takes an expanded sense of reality and objectivity, a concept that tightens the culture of evidence and the cultivation of contextualized initiatives.

\section{Educational Hubs and the Multiversities}

As nations integrate more fully into a global system, educational systems have become not only boundless and seamless but expansive. Revolutionizing programs and courses, transdisciplinary integration, technology transfer, resource mobilization, K-economy workforce escalation, cultural exchange among others affirm that the global environment among universities are undergoing distinctive evolution and revolution. However, universities crossing new borders belong to the efficient- a harsh but inevitable reality where quality and excellence, the agenda of survival, are the essential norms of the global culture. In a glonacal educational climate, most of the initiatives are believed to 
be the offshoots of globalization. Contenders and drivers of internationalization emerge like the USA, the UK and Asian countries such as Singapore, Malaysia, South Korea and China- these countries did embrace the competive marketdriven view of higher education (Sidhu \& Kaur). ${ }^{4}$ To this effect, countless strategic responses toward national transformation of higher education institutions are employed in reframing the 'educational hubs' concept (Marginson, Kaur \& Sawir). ${ }^{5}$ Moreover, national governments adapted a comprehensive educational reform, starting with the comprehensive review of higher education systems, followed by introducing reforms in adherence to international consultancy and advices, and finally improving institutional governance through pro-competition policy instruments and expanding transnational higher education (Mok). ${ }^{6}$

For more than a decade, universities turned-global villages have been evolving into a global university with more mobility, expanded constituencies and system, transborder researches and partnerships, continuous inflow of foreign experts and students, increased international presence through world ranking, accreditation, and alliances are a handful of recent global initiatives that signal the emergence and growth of multiversities (Marginson). ${ }^{2}$ What multiversities showcase is the quest to internationalize their systems (Hayhoe) ${ }^{7}$ and advance their global capacities configured from their sustained roles in research and technology transfer for industrial and economic growth (Sigurdson). ${ }^{8}$ Thus, to remain responsive, relevant and powerful educational player-provider, global universities or multiversities are constituted to evolve as critical researchers from the hangovers of cultural routine and eventually to step up as catalyzers of change and learning. The succeeding presentation argues that the upsurge of knowledge-economy workers: those who can optimally propel technology transfer and incubate practical researches for the sake of social and economic utility are mitigated by a profound mind works espoused by the culture of evidence and willful shift in thinking and practice, a preclusion of the tradition of intervention.

\section{The Culture of Evidence: Enhancing Excellence}

Given the broad frontiers of Humanities, extensiveness and intensity of intellectual glonacal connections stand boundless and multifarious. The propensity of seiving a volume of possibilities, ideas and initiatives from various information sources delineates the existence of expert practitioners. The culture of evidence situates the explicit utilization of data and research in decision making (Millet, Payne, Dwyer, Stickler, \& Alexion $)^{9}$. Winning a proposition that a new idea is accepted, or profitable suggests that the thinking culture of practitioners bears intellectual rigor and reverberates a distinct and empowered voice that permeates the global sphere. Here, the idea of voice should be understood as a community of practice where practitioners question critically (research-driven) their current and longcherished practices, where their practices are publicly shared and critiqued (expert presentation) by a community of practitioners, and where their exemplary practices are critiqued and refereed by a community of experts. In sum, the thinking culture is one that advocates evidences of enhanced excellence. If educational systems are looking out for global convergence pathways (Marginson, Kaur \& Sawir) ${ }^{5}$ and seeing practitioners as knowledge- \& creativedriven workers (Zhao) ${ }^{10}$, the innovative culture must be far ahead of their times. This is to say that the culture of evidence in today's fast-moving and multi-categoricalbreaking environment translates into the incubation of creative,implementable and radical breakthroughs, a great leap forward from the rules of conventionality.

The culture of evidence as enhanced excellence are yet to be cultivated and cultured. Incidences and acts of divisibility and exclusivity have been waging irreversible impacts to the academe. Inclusive practices such as harmony and connectivity at the interpersonal and transnational levels have stood elusive. Personal and social barriers due to variation and difference demistify individual and group potentials. Any attempt to advance excellence, the workforce's potentials are recognized as the ultimate guide toward empowerment, with the different-others not to work-in-captive but in co-existent with the locals. In the Arts and Humanities, the culture of using the informed judgement of the academic community heigthens the participation, ownership and intergenerational mobility of individual members. Similarly, global leaders flex and bend inorder to achieve a sound fusion of intangibles and tangibles from the local, national to the global spectra into their leadership styles.

In the institutional level, imagine reactions portrayed when experts are asked to do something not consistent with their abilities and backgrounds. Will there be a free-flowing talk, intermittent inquiries, sharp interrogations, or will there be just plain silence? Reactions and responses are predictably varied but threshing out the matter is one convergent platform to be dealt with increasing complexity and interdependence. In the personal level, will each one have the courage and the opportunity to speak out his mind? Will timing, purpose, space and pace be precursors in soliciting ideas thus increasing the likelihood of a steady stream of ideas? In general, strengthening the culture of excellence takes shape on the precepts of intellectual integration. It communicates that organized networks nurture distributed influence and render strong evidence of empowerment.

\section{The Tradition of Intervention: Catalyzing Change}

Experts argue that global changes continue to threathen management requisites in organizations and propel the workforce to broaden its transformative capacity. With the advent of internationalization, transnational responsiveness has become valuable development strategies (Marginson, Kaur \& Sawir). ${ }^{5}$ They gravitate around the same global sphere, tipping the more contemporary phase of globalization. Reciprocally, critical and creative exploration over the appropriate control and selective use of a multitude positioning, initiating changes and aligning initiatives for 
the sake of local sustainability and international recognition such as world ranking, global alliances and accreditation

Infusing this integrative idea to the organizational level remains constructive. If and when an organization's intent is to create a culture that permeates openness, allowing people across the rungs to speak up is a key point of intervention. Look at the disparity between seasoned and novice group leaders, is the flow of expertise expanding or shrinking? Ronald Heifetz, one of the world's leading leadership experts and the director of Leadership Education Project at Harvard believes that a willingness to speak up and speak out is the root of innovation and that cultures well positioned to innovate teach/train their people to challenge their assumptions and practices. In civil societies lurk a mix of dysfunctional individuals and group of visionaries, dissenters and other useful troublemakers often labeled potential 'radices' but they are people who speak truth to power, heretics, and mavericks. Their existence reflects that excellence configures when the system listens to and acts on people who cause dissent. The sustained belief of enticing them to disclose what and why they do things provides them the space to excel and innovate. For example, the tradition of responsiveness in companies such as Sony, Microsoft, Nortel, and Hawlett-Packard proves that institutionalizing a system policy for new thinking, leading new products, new services, and new ways of doing after harboring serendipitous ideas from multi-lateral minds are borne from the 'meeting' of great minds. Working on cross-purposes, great minds break away from the norm to speak the language of novelty. When different cultures (e.g. disciplines) meet, be it at the societal or in the organizational level, ideas about why and how new things would be done often clash. Hence, tensions are inherent in the system and may appear threatening to tradition, power, and authority. However, the modicum of working well together can generate enormous impact, or better still can translate tension-provoking stimuli into home-grown inducers when the system bent out of shape. Interdisciplinary integration wins against the battle of mediocrity, sloppy decisions, and irrational dissent. If embraced with intentionality, creative spaces exist, quality resides; and atop quality, excellence thrives.

\section{Conclusion}

To encapsulate, reconstituting the culture of evidence and the tradition of intervention is and always be a systemic craving, envisaged as a lifetime vision-mission of universities and multiverties. Studded with unprecedented sophistications, the glonacal climate carries a dynamic potency of moving new ideas and shared work across the trans-cultural milieu. A persistent battle cry, enhancing excellence and catalyzing change in the Arts and Humanities by virtue of its existence draws the growth of a critical mass of thinkers, a new tribe of practitioners who are positioned to create and diffuse a dense of informed practices and exemplary efforts from the systemic, cultural, and social standpoints.

\section{Source of funding}

None.

\section{Conflict of interest}

None.

\section{References}

1. Chin, J \& Trimble, J. (2015). Diversity and leadership. Thousand Oaks, California: Routledge Publication Ltd.

2. Marginson, S. (2010). The rise of the global university: 5 new tensions. The chronicle of higher education at http://www.chronicle.com retrieved on March 1, 2018.

3. Owens, R. \& Valesky, T. (2015). Organizational behavior in education. Leadership and school reform. USA: Pearson Education, Inc.

4. Sidhu, G. \& Kaur, S. (2011) Enhancing global competence in higher education: Malaysia's strategic initiatives pp.220234 in Higher Education in the Asia-Pacific: Strategic responses to globalization by Marginson, K., Kaur, S., \& Sawir, E. Eds.

5. Marginson S., Kaur S., \& Sawir E. (2011). Higher education in the Asia-Pacific. Strategic responses to globalization. New York, USA: Springer Publishing.

6. Mok K. Singapore's global education hub ambitions. Int $J$ Educ Manag, 2008;22(6):527-46.

7. Hayhoe R. (2014). China through the lens of comparative education at tps:books.google.com.ph retrieved on March 1, 2018.

8. Sigurdson K. (2013). Clark Kerr's multiversity and technology transfer into the modern American Research University. College Quarterly, 2(16) at college quarterly.ca/2013-vol1 retrieved on March 1, 2018.

9. Millet C., Payne, D., Dwyer C., Stickler L., \& Alexion J. (2008). A culture of evidence III: An evidence-centered approach to accountability for student learning outcomes at http://www.ets.org>pdf>COEII_report retrieved on March $1,2018$.

10. Zhao Y. (2012). World class learners. London, UK: Sage Publishing Company.

11. Horibe F. (2001). Creating the culture of innovation. Ontario, Canada: John Wiley \& Sons.

How to cite this article: Valdez NP. The glonacal climate in education: Reconstituting the culture of evidence and tradition of intervention in humanities. $J$ Manag Res Anal 2019;6(3):147-9. 